\title{
PELAKSANAAN PERAWATAN DAN PELESTARIAN BAHAN PERPUSTAKAAN DI PERPUSTAKAAN IPB UNIVERSITY
}

\author{
Roni \\ Pustakawan Perpustakaan IPB University \\ ronny@apps.ipb.ac.id
}

\begin{abstract}
Abstrak
Penelitian ini bertujuan untuk mengetahui pelaksanaan kegiatan perawatan dan pelestarian bahan perpustakaan serta kendala dalam pelaksanaannya di Perpustakaan IPB University. Penelitian ini menggunakan metode penelitian kualitatif deskriptif. Hasil penelitian diperoleh kesimpulan bahwa kegiatan pelestarian dan pemeliharaan bahan perpustakaan di perpustakaan IPB University belum dilaksanakan secara maksimal sebagaimana mestinya. Banyak bahan perpustakaan yang masih dalam keadaan rusak karena beberapa kendala diantaranya keterbatasan dana yang khusus untuk kegiatan ini serta terbatasnya sarana dan prasarana dan tenaga ahli yang mampu untuk mengerjakan kegiatan perawatan dan pelestarian bahan perpustakaan. Kegiatan perawatan dan pelestarian di Perpustakaan IPB University masih dilakukan dengan sangat sederhana, seperti: membersihkan rak tempat penyimpanan bahan pustaka dan penjilidan buku rusak.
\end{abstract}

Kata kunci : perawatan bahan perpustakaan, pelestarian bahan perpustakaan, sumberdaya manusia

\begin{abstract}
This study aims to determine the implementation of the maintenance and preservation of library materials and the obstacles in their implementation at the IPB University Library. This study uses descriptive qualitative research methods. The results of the study concluded that the preservation and maintenance of library materials at the IPB University library had not been carried out optimally as it should. Many library materials are still in a state of disrepair due to several obstacles including limited funds specifically for this activity as well as limited facilities and infrastructure and experts who are able to carry out maintenance and preservation activities for library materials. Maintenance and preservation activities at the IPB University Library are still carried out very simply, such as: cleaning shelves where library materials are stored and binding damaged books.
\end{abstract}

Keywords: maintenance of library materials, preservation of library materials, human resources

\section{Pendahuluan}

Teknologi informasi saat ini sangat pesat perkembangannya, sehingga masyarakat dengan mudah mengakses dan menelusur informasi melalui internet. Perkembangan teknologi digital sekarang ini semakin canggih sehingga terjadi perubahan yang sangat besar terhadap dunia informasi. Kebutuhan masyarakat akan informasi kini telah dimudahkan dalam mendapatkan informasi dengan berbagai cara, serta mudah dalam memperoleh fasilitas dari teknologi digital dengan cara yang lebih cepat dan tepat dalam memenuhi kebutuhan informasinya. Namun demikian keberadaan perpustakaan hingga kini terus dicari dan dibutuhkan dalam memperoleh berbagai informasi.

Perkembangan teknologi informasi memberikan kemudahan dalam memperoleh berbagai informasi di internet, akan tetapi keberadaan perpustakaan masih banyak dibutuhkan oleh pemustaka dalam memperoleh koleksi tercetak. Bahan perpustakaan tercetak yang tersedia di perpustakaan baik terbitan terbaru maupun terbitan lama masih banyak 
digunakan baik sebagai ilmu pengetahuan maupun sebagai hiburan intelektual. Perpustakaan sebagai sumber informasi tentunya harus dapat menyediakan berbagai kebutuhan informasi bagi pemustaka-nya. Dalam memberikan pelayanan terbaik kepada pemustaka maka perpustakaan harus mampu memberikan layanan informasi yang berkualitas, agar dapat mewujudkan perpustakaan sebagai sumber informasi bagi masyarakat pengguna perpustakaan. Tentunya informasi tersebut diperoleh dari bahan perpustakaan yang berkualitas

Beberapa bahan perpustakaan tercetak baik buku, jurnal maupun karya tulis ilmiah seperti laporan penelitian, skripsi, tesis disertasi maupun bahan tercetak lainnya, hampir semuanya berbahan dasar kertas sehingga keberadaan bahan perpustakaan tersebut sangat mudah rusak seperti robek, terbakar, dan juga kena noda. Penyebab kerusakan pada bahan perpustakaan berbahan dasar kertas, tergantung pada kualitas kertas, keberadaan iklim setempat, keberadaan suhu ruangan serta pelaksanaan perawatannya.

Keberadaan koleksi perpustakaan tercetak di Perpustakaan IPB saat ini banyak mengalami kerusakan yang disebabkan oleh kondisi bahan perpustakaan yang terbilang koleksi lama atau koleksi yang rusak karena disebabkan oleh serangga. Oleh sebab itu perpustakaan hendaknya melakukan perawatan dan pelestarian bahan perpustakaan. Untuk dapat melaksanakan perawatan bahan perpustakaan, pihak perpustakaan harus mengetahui kondisi bahan perpustakaan yang ada di perpustakaan dengan melalui survei terhadap keberadaan koleksi secara langsung dalam lapangan, sehingga dengan demikian akan diketahui bagaimana cara perawatan yang harus dilakukan. Dengan adanya fenomena tersebut di atas maka akan dilakukan penelitian yang berkaitan dengan bagaimana perawatan dan pelestarian bahan perpustakaan di Perpustakaan IPB University.

Tujuan penelitian ini adalah: Pertama untuk mengetahui perawatan dan pelestarian bahan perpustakaan di Perpustakaan IPB University, dan kedua adalah untuk mengetahui kendala perawatan dan pelestarian bahan pustaka di Perpustakaan IPB University. Penelitian ini menggunakan metode penelitian kualitatif deskriptif, dengan melakukan wawancara kepada petugas di bagian perawatan dan pelestarian serta melakukan observasi pada beberapa bahan perpustakaan yang bermasalah dan mempelajari berbagai sumber pustaka yang berkaitan dengan pelaksanaan perawatan dan pelestarian bahan perpustakaan. Penerapan metode Deskriptif kualitatif dalam penelitian ini bertujuan untuk mengkaji suatu masalah dalam pelaksanaan perawatan dan pelestarian bahan perpustakaan secara mendalam dan menyeluruh. (Moeloeng, 2016).

\section{Tinjauan Pustaka}

Bahan perpustakaan yang menjadi koleksi di perpustakaan adalah sumber informasi yang bernilai tinggi dan sangat penting. Oleh karena itu bahan perpustakaan yang menjadi koleksi perpustakaan harus dirawat atau dilestarikan (Turwulandari, 2019) Kegiatan perawatan dan pelestarian bahan perpustakaan merupakan hal yang penting dan harus dilakukan oleh setiap perpustakaan. Pustakawan dan staf teknis perpustakaan terutama di bagian perawatan dan pelestarian perlu memahami penyebab terjadinya kerusakan koleksi, sehingga dengan mudah dilakukan tindakan pencegahan. Sedangkan apabila koleksi sudah terlanjur rusak, akan susah untuk memperbaikinya selain itu juga akan memerlukan biaya yang cukup banyak. 
Tujuan dilaksanakannya perawatan dan pelestarian bahan perpustakaan adalah salah satu usaha agar koleksi bahan perpustakaan selalu tersedia dan siap untuk dipergunakan. Alih media merupakan suatu usaha dalam melakukan pelestarian bentuk fisik bahan perpustakaan dan melestarikan kandungan informasi seperti dalam bentuk microfilm, mikrofis, foto reproduksi dan fotokopi atau melestarikan kedua duanya, yaitu bentuk fisik dan kandungan informasinya (Ibrahim, 2013)

Sedangkan fungsinya menurut Martoatmodjo (1993) terdiri dari 8 fungsi, yaitu 1) Melindungi bahan perpustakaan dari berbagai faktor terjadinya kerusakan. 2) Mengawetkan bahan perpustakaan agar tidak cepat rusak dan tahan lama dalam pemanfaatannya. 3) Menjaga bahan perpustakaan supaya selalu bersih. 4) Memberikan pendidikan kepada pemustaka dalam menggunakan bahan perpustakaan. 5) Diperlukan kesabaran dalam pelaksanaan perawatan dan pelestarian. 6) Kegiatan yang membutuhkan keterlibatan pemustaka dan pustakawan sebagai fungsi sosial. 7) Fungsi ekonomi dalam perawatan dan pelestarian yang baik akan menghemat biaya. 8) Fungsi keindahan agar dapat menambah daya tarik bagi para pengunjung perpustakaan.

Pencegahan terjadinya kerusakan bahan perpustakaan merupakan suatu tindakan yang baik dan tepat yang dilakukan sejak dini, dari pada melaksanakan perbaikan bahan perpustakaan yang sudah rusak keadaannya. Pencegahan terjadinya kerusakan bahan pustaka seperti yang ditulis oleh Soraya \& Damayanti (2010) dapat dilakukan sebagai berikut:

1. Mencegah terjadinya kerusakan koleksi faktor biologi, yaitu dengan melakukan fumigasi pada koleksi perpustakaan dengan cara pengasapan berbahan kimia

2. Mencegah terhadap kerusakan bahan perpustakaan oleh manusia

a) Susunan bahan perpustakaan tidak padat.

b) Cara mengambil bahan perpustakaan harus benar.

c) Melaksanakan sosialisasi kepada Pustakawan dan pemustaka

d) Melakukan kontrol saat pengembalian koleksi.

e) Memberikan sanksi kepada pemustaka yang merusak koleksi.

f) Saran dan prasaran yang baik.

3. Mencegah dan Waspada terhadap kebakaran

a) Secara berkala melakukan pengecekan jaringan kabel listrik.

b) Meletakan alat pemadam kebakaran di tempat yang tepat

c) Pelarangan merokok di ruangan perpustakaan.

Perawatan bahan perpustakaan dilaksanakan dengan berbagai cara yaitu: pembasmian, pembersihan, deasidifikasi, pemutihan bahan kertas, membersihkan noda dan sellotape, juga dengan cara melakukan penyiangan bagi bahan perpustakaan yang sudah rusak dan berpenyakit.

Selain perawatan bahan perpustakaan juga dilakukan perbaikan. Jenis perbaikan bahan perpustakaan seperti

Melakukan penambalan untuk bahan perpustakaan yang rusak dengan tissue jepang atau tissue berperekat

1. Merekatkan bagian kertas yang robek menggunakan tissue jepang atau hand made paper.

2. Melakukan pelapisan bagian belakang untuk memperkuat.

3. Melakukan laminasi untuk bahan perpustakaan rusak berat. 
4. Enkapsulasi, yaitu bahan perpustakaan dilapisi dengan double side tape.

5. Penjilidan dan perbaikan sampul buku.

Pelestarian kandungan informasi dilakukan dengan tujuan untuk melestarikan fisik asli bahan perpustakaan dan informasi yang terkandung. Pelestarian ini dilaksanakan dengan melakukan alih media. Beberapa cara dalam melestarikan koleksi seperti yang ditulis oleh Asaniyah (2019). Pertama adalah digitalisasi atau alih media informasi, sehingga kandungan informasi dapat digunakan pemustaka. Ke-dua yaitu restorasi dan Ke-tiga adalah fumigasi yaitu pengasapan. Fumigasi ini seharusnya dilakukan secara berkala.

Beberapa kendala dalam pelaksanaan perawatan dan pelestarian nenurut Sulistyo-Basuki

adalah:

1. Kurangnya sumberdaya manusia yang melaksanakan pelestarian di perpustakaan.

2. Tidak adanya dana untuk melaksanakan pelestarian koleksi.

3. Bahan perpustakaan tercetak menggunakan kualitas kertas kurang baik

4. Ruang untuk keperluan pelestarian dan perawatan koleksi tidak memadai

\section{Pembahasan Hasil Penelitian \\ Koleksi Perpustakaan IPB \\ University}

Koleksi bahan perpustakaan di Perpustakaan IPB University terdiri dari buku, laporan penelitian, referensi, skripsi, tesis, disertasi, majalah, dan koran serta beberapa koleksi on line. Di Perpustakaan IPB University memiliki koleksi Buku 56.254 judul dan 93.535 eksemplar, Skripsi 80.191 Judul, Tesis 19.685
Judul, Disertasi 4.243 Judul (Institit Pertanian Bogor. Perpustakaan, 2021). Secara umum kondisi bahan perpustakaan tersebut dalam keadaan baik, akan tetapi ada beberapa bahan perpustakaan yang rusak dan perlu diadakan perbaikan, dan perawatan. Beberapa bahan perpustakaan terbitan lama masih tetap dipertahankan karena masih banyak pemustaka yang memerlukan bahan perpustakaan tersebut, untuk itu sebaiknya bahan perpustakaan dirawat dan dilestarikan agar tetap bisa dipakai oleh pemustaka.

\section{Kerusakan Bahan perpustakaan}

$\begin{array}{lcr}\text { Jenis } & \text { kerusakan bahan } \\ \text { perpustakaan } & \text { yang ada di } \\ \text { Perpustakaan } & \text { IPB University } \\ \text { berdasarkan pengamatan langsung, } & \text { diparang } \\ \text { dipengaruhi oleh: Pertama adalah }\end{array}$ faktor biologi, Bahan perpustakaan tercetak umumnya berbahan dasar kertas, dimana bahan perpustakaan ini terdiri dari selulosa, perekat dan protein yang menjadi sumber makanan bagi beberapa mahluk hidup. Ke-dua adalah faktor manusia, diantaranya ada beberapa pemustaka yang kurang peduli dan kurang berhati-hati dalam menggunakan koleksi perpustakaan.

\section{Peralatan dalam Perawatan dan} Pelestarian Bahan Perpustakaan

Pelaksanaan perawatan dan pelestarian bahan perpustakaan di Perpustakaan IPB University secara teknis hanya menggunakan alat yang sangat sederhana, untuk perawatan bahan perpustakaan hanya menggunakan kapur barus, kipas angin, lampu, ventilasi dan vacuum cleaner. Sedangkan untuk perbaikan menggunakan lem, kain kasa, isolasi dan staples sedangkan untuk pelestarian bahan pustaka hanya menggunakan scanner dan mesin fotokopi. 


\section{Perawatan dan Pelestarian Bahan Perpustakaan di Perpustakaan IPB University}

Berbagai tahapan yang dilaksanakan dalam kegiatan perawatan dan pelestarian bahan perpustakaan di Perpustakaan IPB University adalah :

\section{Pencegahan Kerusakan}

a) Mencegah kerusakan bahan perpustakaan yang disebabkan oleh faktor biota yaitu melakukan beberapa upaya untuk mencegah supaya serangga tidak datang, untuk pencegahan dengan menggunakan kapur barus dan bahan kimia lainnya. Sedangkan untuk pencegahan yang disebabkan oleh jamur, bisa melakukannya dengan fumigasi, akan tetapi selama ini tidak dilakukan karena terkendala oleh dana.

b) Mencegah kerusakan bahan perpustakaan karena faktor fisika, yaitu dengan menghidupkan kipas angin, pengaturan ventilasi udara, menggunakan gorden supaya tertutup dari cahaya matahari.

c) Mencegah kerusakan bahan perpustakaan yang disebabkan oleh manusia yaitu dengan melakukan sosialisasi kepada pemustaka atau pengguna dan membuat beberapa pengumuman yang berkaitan dengan kerusakan bahan perpustakaan.

\section{Perawatan Bahan Perpustakaasn}

Perawatan bahan perpustakaan adalah salah satu upaya agar bahan perpustakaan terhindar dari kerusakan. Dalam pelaksanaannya perawatan yang dilakukan di perpustakaan IPB University saat ini baru melakukan perawatan bahan perpustakaan dengan cara yang sangat sederhana dengan cara membersihkan dari kotoran debu supaya bahan perpustakaan tersebut tidak rusak.

\section{Perbaikan Bahan pustaka}

Perbaikan bahan perpustakaan yang dilakukan Perpustakaan IPB University dilakukan hanya bagi bahan perpustakaan yang rusak ringan karena terkendala peralatan, dana, dan juga belum memiliki ruangan khusus/laboratorium untuk kegiatan ini dan bahan perpustakaan yang bisa diperbaiki seperti: sampul buku yang lepas, halaman yang lepas atau robek, bahan pustaka yang terbelah menjadi dua, dan jilidan yang lepas. Jadi yang baru dilaksanakan hanya mengelem, menjilid ulang menggunakan isolasi agar bahan perpustakaan yang rusak tersebut menjadi kuat. Selain itu Perpustakaan IPB University memang selalu melakukan penyiangan, karena ilmu pengetahuan terus berinovasi.

\section{Pelestarian Bahan Pustaka}

Kegitan pelestarian yang selama ini baru dilakukan di Perpustakaan IPB University adalah dengan alih media, seperti semua karya tulis IPB dalam bentuk Skripsi, tesis, disertasi ataupun karya tulis dalam bentuk laporan yang biasa dikelompokan dalam IPBana, ini dikoleksi dengan dua versi yaitu tercetak dan dalam bentuk digital.

\section{Kendala Perawatan dan Pelestarian Bahan Perpustakaan}

1. Kegiatan perawatan dan pelestarian bahan perpustakaan masih banyak kendala dengan terbatasnya keberadaan sumber daya manusia. Dengan demikian Perpustakaan IPB sangat membutuhkan SDM dengan keahlian dalam pelaksanaan perawatan dan pelestarian bahan perpustakaan.

2. Minimnya keberadaan sarana dan prasarana, peralatan yang dibutuhkan dalam pelaksanaan kegiatan perawatan dan pelestarian bahan perpustakaan, sehingga 
bahan perpustakaan tidak bisa dilakukan perawatan dan pelestarian dengan maksimal.

3. Minimnya sumber dana, alokasi dana untuk kegiatan perawatan dan pelestarian bahan perpustakaan sudah lama tidak dialokasikan, sehinnga perawatan dan pelestarian tidak dilaksanakan sesuai kebutuhan.

4. Di Perpustakaan IPB University tidak memiliki ruangan khusus yang memadai untuk kegiatan perawatan dan pelestarian bahan pustaka.

\section{Kesimpulan}

Hasil penelitian ini dapat disimpulkan bahwa kegiatan perawatan dan pelestarian bahan perpustakaan di Perpustakaan IPB University belum dilaksanakan secara maksimal sesuai yang dibutuhkan. Selama ini kegiatan ini hanya berusaha membersihkan rak penyimpanan koleksi dan penjilidan bahan perpustakaan yang rusak. Sedangkan untuk pelestarian selama ini sudah dilakukan alih media terutama semua bahan perpustakaan karya tulis skripsi, tesis dan disertasi. Beberapa kendala dalam pelaksanaan perawatan dan pelestarian bahan perpustakaan di Perpustakaan IPB University adalah: Terbatasnya kemampuan SDM dalam pelaksanaan perawatan dan pelestarian, minimnya keberadaan sarana dan prasarana, belum tersedianya ruangan khusus untuk pelaksanaan kegiatan perawatan dan pelestarian bahan perpustakaan dan tidak ada alokasi dana yang khusus untuk kegiatan perawatan dan pelestarian sehingga kegiatan ini belum bisa dilaksanakan dengan maksimal.

\section{DAFTAR PUSTAKA}

Asaniyah, N. (2019). Pelestarian koleksi langka melalui restorasi. Buletin Perpustakaan Universitas Islam Indonesia Vol. 2, No. 1 , 93-104.

Ibrahim, A. (2013). Perawatan dan Pelestarian Bahan Pustaka. Khasanah Al-Hikmah Vol. 1, No. 1.

Institut Pertanian Bogor. Perpustakaan (2021). Laporan Tabunan Perpustakaan IPB University 2020. Bogor: Perpustakaan IPB.

Martoatmodjo, K. (1993). Pelestarian Baban Pustaka. Jakarta: Depdikbud.

Moleong, L. J. (2016). Metodologi Penelitian Kualitatif. Bandung: PT. Remaja Rosdakarya, 2016. Bandung: Remaja Rosdakarya.

Soraya, A., \& Damayanti, L. (2010). Pelestarian Baban Pustaka: Baban Ajar Diklat Calon Pustakawan Tingkat Abli. Jakarta: Perpusnas RI.

Sulistyo-Basuki. (1991). Pengantar Ilmu Perpustakaan. Jakarta: Universitas Terbuka.

Turwulandari, N. (2019). Perawatan dan Pelestarian Bahan Pustaka di Perpustakaan Universitas Airlangga. Jurnal Perp[ustakaan Universitas Airlangga, Vol. 9, No. 2, 80-82. 